Michael Eldred:

\title{
Gainful game, set-up, cyberworld
}

\begin{abstract}
:
There is a critique of capitalist market economy that consists in claiming not only that capitalist social relations are uncaring and alienating, nor only exploitative of the working class, but that the process of capitalist economy as a whole is a way of living, today globalized, that has gotten out of hand. Its essential nature is unmasked as a senseless circular movement that, besides ruthlessly exploiting natural resources, demeans human being itself and alienates it from the historical alternative of a purportedly authentic mode of human being rooted in collective, solidaric subjectivity. The present article offers an alternative hermeneutic cast for understanding capitalism as the gainful game that can serve as philosophical orientation in fighting for a free and fair social interplay in which the powers and abilities of free individuals are appropriately and reciprocally estimated and esteemed. This requires, first and foremost, seeing through the fetishisms inherent in the valorization of reified value that the mature Marx identified in his critiques of political economy as the essential nature of capitalism. Such critical insight is necessary for orientation also in today's predicament of the ever more encroaching and ensnaring cyberworld.
\end{abstract}

\section{Agenda}

The gainful game 113

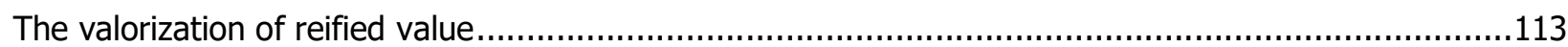

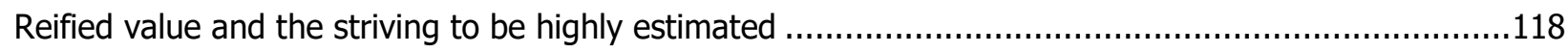

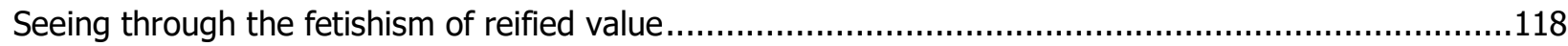

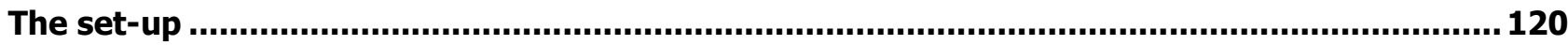

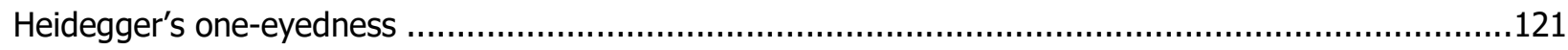

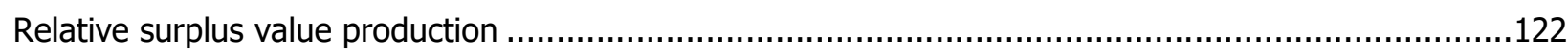

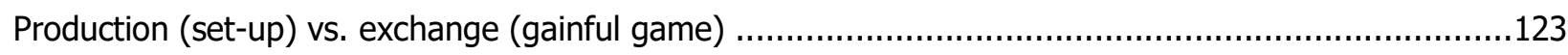

The cyberworld ............................................................................................................ 126

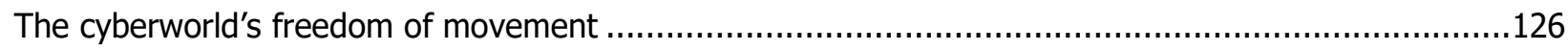

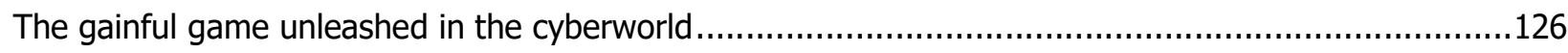

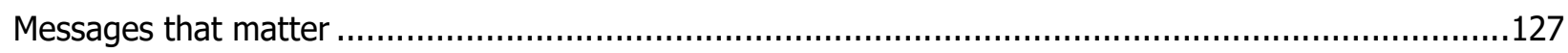

\section{Author:}

\section{Michael Eldred}

- Australian philosopher, mathematician and translator currently living in Cologne, Germany. Academic Qualifications: Ph.D. M.Sc. B.Sc. (Hons.) Univ. Sydney.

- $\triangle$ me@arte-fact.org, $\square$ www.arte-fact.org

- Relevant publications: see the references of this article 


\section{Gainful game, set-up, cyberworld ${ }^{1}$}

\section{The gainful game ${ }^{2}$}

\section{The valorization of reified value}

There is a critique of capitalist market economy and Adam Smith's famous "invisible hand" to be considered that consists in claiming not only that capitalist social relations are uncaring and alienating, nor only exploitative of the working class, but that the process of capitalist economy as a whole is a way of living, today globalized, that has gotten out of hand. Its essential nature is unmasked as a senseless circular movement that, besides ruthlessly exploiting natural resources, demeans human being itself and alienates it from the historical alternative of a purportedly authentic mode of human being rooted in collective, solidaric subjectivity. Elements of such a critique can be unearthed in Marx's critique of capitalism as a process without a conscious social subject, ${ }^{3}$ but they can also be found, with an entirely different focus, in Heidegger's questioning of modern technology against the foil of the alternative of humankind dwelling poetically on the Earth as the "shepherd of being". ${ }^{4}$ Here I shall first focus on Marx and treat Heidegger's conception of the set-up thereafter.

According to the late Marx, who radicalizes and deepens the concept of alienation laid out in his early works, especially the Economic-philosophical Manuscripts of 1844, the essence of capital is the endless, limitless valorization of value, the endless deployment of reified value for self-augmentation through never-ending cycles of money-capital being advanced and returning bloated with a surplus. Such a concept of value is lacking entirely in Marx's early writings of the 19840s. The cyclical valorization of value is a movement which sets itself up and asserts itself "behind the backs" of people, as Marx often puts it. ${ }^{5}$

'Valorization' is the translation of German 'Verwertung', which can mean simply 'use', 'utilization', 'drawing the value or benefit from something', but in the context of Marx's thinking it signifies above all a use of reified value to make more reified value through the circular movement of the advance and return of capital. Valorization is the essential action through which capital holds sway, whereby action here cannot be thought in terms of human action, say, of profit-seeking capitalists, but as an historical hermeneutic cast that has come

\footnotetext{
${ }^{1}$ Many thanks to Astrid Nettling for her critical comments.

${ }^{2}$ Cf. M. Eldred Chapter 9 vi) Social Ontology: Recasting Political Philosophy Through a Phenomenology of Whoness ontos/deGruyter Frankfurt/Berlin 2008/2011, which itself is a thoroughly revised and altered update of Chapter 7 of M. Eldred Kapital und Technik: Marx und Heidegger Röll, Dettelbach 2000. English version: 'Capital and Technology: Marx and Heidegger' in: Left Curve No. 24 May, 2000 Oakland, California USA.

${ }^{3}$ Cf. Marx's investigation of the total, social circulation process of capital in the oft neglected Vol. II of Das Kapita/and the 'Value-form Analytic Reconstruction of Capital (Michael Eldred, Marnie Hanlon, Lucia Kleiber \& Mike Roth) in Critique of Competitive Freedom and the Bourgeois-Democratic State 1984/2010 § 65. The total social circulation process of capital must be regarded as a social movement that is mediated by, i.e. which takes place within, the ontological structure of the fully developed value-forms developed step by step in the value-form analysis. The primary value-forms in order of conceptual development are use-value/exchange-value, commodity, money, capital, surplus value, wages, profit of enterprise, interest, ground-rent, and the quadruple of these last four as revenue- or income-sources. This complex ontological structure can be termed a "constellation of being" in the Heideggerian sense. It may also be termed an 'hermeneutic cast' of an historical age. In my Capital and Technology op. cit., I have termed this constellation/cast "das Gewinnst", "das Gewinn-Spiel" or the gainful game in which human beings are caught up as players competing for income, not only for profit.

${ }^{4}$ M. Heidegger 'Brief über den 'Humanismus" in Wegmarken Klostermann, Frankfurt/M. 2/1978 p.338.

5 "hinter dem Rücken", e.g. Gr.:136, 156, MEW23:59. This is also akin to Hegel's conception of Weltgeist (spirited world-mind) which asserts itself in the history of the world.
} 
over everything, enticing human beings with its manifold possibilities of gain. To think valorization as attributable to an hermeneutic cast goes against the grain of Marxian thinking, of course, in which it would have to be regarded as an ahistorical fetishism that could be resolved into a figure of "bourgeois false consciousness" by deciphering value and valorization as ostensibly a "social product just like language" (MEW23:88) and a class ideology to boot.

Nevertheless, just as we shall see when discussing Heidegger's thinking on the set-up that the essence of technology is nothing technical, the essence of capital is nothing economic; the valorization of value cannot be thought ultimately as an economic phenomenon but solely as an historical casting of human being within the open clearing of an age. Marx's critique of political economy is not a theory of capitalist economy with the appropriate specialized concepts; rather, as critique, it is a questioning and a presentation of a social ontology of capital which - now expressed in Heidegger's language - is not merely a human "machination". The analysis of the value-form, that has plagued and puzzled readers of the first chapter of Das Kapitalever since its first publication, ${ }^{6}$ and has been largely ignored by Marxism itself, is a social ontology of reified value, as the very word 'form' indicates, a term that goes back to Plato and Aristotle as the Latin translation of ' $1 \delta \dot{\varepsilon} \alpha$ and $\mu \circ \rho \phi \eta$, terms originally coined to say the being of beings, i.e. their metaphysical 'beingness'.

If the valorization of value expresses the essential nature of capital, i.e. its being, ${ }^{7}$ then capital is gathered into the various modes of valorization. In this gathering, everything that is reveals itself to be valorizable, i.e. as capable of being drawn into a circuit of valorization, of apparent self-augmentation of value. Value is neither money nor capital but the essence of valorizing, which makes all beings appear as valorizable. With the reification of value in the sociating thing, money, and the self-movement of this value-thing through transformations into commodities and production process in circuits of self-augmentation, the connection of value with being valuable for human beings is lost, alienated. The movement is out of human hands and instead humans themselves are enticed and caused to move by an eery power of endless augmentation of value they do not master.

Whereas the phenomenon of value is to be uncovered first of all in things and people being valuable for living, i.e. in enhancing a way of life, and exchange-value is to be understood as a derivative form of value that arises in the social practice of exchange, ${ }^{8}$ Marx analyzes in his ever renewed critiques of political economy from 1857 on an inversion of value in which it becomes a self-moving subject of its own augmentation and as such a reified social power. ${ }^{9}$ This is the Marxian concept of fetishism, which assumes various phenomenal forms, starting with commodity and money fetishism and proceeding to capital fetishism and interest fetishism. ${ }^{10}$ The common essential trait of these fetishisms is that value has assumed a reified form remote from any human appreciation of value as valuable for living that initiates a movement within a topsy-turvy world of apparently self-augmenting self-movement of reified value. "It is only the determinate social relation of humans themselves which here assumes for them the phantasmagoric form of a relation among things. ${ }^{111}$ That certain

\footnotetext{
${ }^{6}$ There are in fact no less than four different versions of the incipient value-form analysis published by Marx himself: in On the Critique of Political Economy MEW:13 (1859), Chapter 1 of the first edition of Das Kapital(1863), an Appendix to the first edition, and the second edition of Das Kapital(1867).

${ }^{7}$ And its being turns out to be its 3D-temporality; cf. M. Eldred A Question of Time 2015.

${ }^{8}$ Cf. Chapter 5 i) of M. Eldred Social Ontology 2008/2011.

${ }^{9}$ Cf. ibid. Chapter 10 i).

${ }^{10}$ Cf. ibid. Chapter 6 viii).

11 "Es ist nur das bestimmte gesellschaftliche Verhältnis der Menschen selbst, welches hier für sie die phantasmagorische Form eines Verhältnisses von Dingen annimmt." K. Marx Das Kapita/Vol. I MEW23:86.
} 
things appear to inherently possess value in itself is just as fetishistic as a sum of money inherently being able to endlessly yield of itself amounts of interest.

Value shows itself quantitatively as well as qualitatively in the potential or realized exchange against money, but, despite the real appearance of reification, it cannot be identified with the thing 'money', for this is already an inversion; rather, money is a form of appearance of value. Nevertheless, once this value reification and fetishism is established (preontologically in understanding, ontologically in philosophical thought and historically in an age of the world), the essential nature of capital expresses itself above all in money and money-capital's augmenting self-movement. The capitalist world gathers itself crystallinely in money; in the thing (res) 'money', the world worlds capitalistically, as soon as the movement of valorization, i.e. the valueaugmenting deployment of all beings, achieves an autonomy and absoluteness vis-à-vis human beings. The absoluteness consists in reified value no longer having any relation to how things and people's abilities are valuable for human living.

In the capitalist world, all beings have a direct or indirect relation to money; the totality of beings passes like Alice through the value-mirror, money, into an inverted world of capital valorization. To my mind, the critique of capitalist economy amounts to deciphering this inversion and is hence, in the first place, an achievement of thinking through which the world itself presents itself differently, stripped of the fetishistic and deceptive forms of appearance of reified value. This conception of mine flies in the face of Marx's famous eleventh thesis on Feuerbach from 1845, according to which it is insufficient to 'merely' interpret the world; the point is to change it. Pace Marx, to interpret the world differently from the ground up in an alternative hermeneutic cast amounts to changing it fundamentally.

If reified value is the way the totality of beings opens up and shows itself hermeneutically in its very being, and also is kept in perpetual movement as a metabolism of reified value passing through various value-forms, the question arises, what the gathering of valorization in the present historical age should be called. With this naming, the historico-hermeneutic essence of modern capitalist society would also be named. Instead of tracing back value to social labour in an abstractly universal form (as Marx does in his critiques of political economy, thus suggesting that a socialized human subject could re-invert the reification of value into a conscious sociation of labour ${ }^{12}$ according to a total social plan that would do away with reified social relations), labour itself now also has to be thought in tracing it back into its groundless ground in the infinite, apparent self-movement of valorization, since labouring humans, too, are merely used by this reified valorizing movement that holds sway in the Modern Age. They succumb to a wage-labour fetishism insofar as they, too, set their highest sights on and are content with having secure, adequately paid jobs provided by capital.

I call the gathering of valorization that attains domination in the capitalist world in an essential sense the gathering of the gainable or, simply, the gainful game (Gewinnst, Gewinn-Spie). The gainful game as the gathering of the gainable is here neither profit nor winnings nor merely a purely economic magnitude, nor only the successful result of a human struggle or human labour, but the open gathering of all the essentially risky opportunities for gain, which holds sway groundlessly as the kernel of capitalism's truth. 'Risk' is here conceived broadly, as it must be in phenomeno-ontology, to encompass also all apparently risk-free, secure opportunities for gain; risk itself, however, is inherent in the groundless nature of social interplay, which will be discussed below. Capitalism's truth is an hermeneutic disclosure that opens up as a world of apparent

\footnotetext{
${ }^{12}$ Marx remarks ironically, "Let us, for a change, finally imagine an association of free people..." (Stellen wir uns endlich, zur Abwechslung, einen Verein freier Menschen vor,... Das Kapita/ Vol. I MEW23:92)
} 
opportunity to a desiring, and not merely needful, human being, whilst appropriating human being to itself through inducing and encouraging human being's endless desire for more.

Within this gathering as a constellation of being in an historical age, enterprising human beings are enticed to cast their selves into the endless, uncertain pursuit of gain as its unwitting agents. Those who are risk-averse and less enterprising are content with gaining a secure, regular wage-income. Such gain therefore is not only profit, but comprises all the four income sources as analyzed by Marx in the third volume of Das Kapital as revenue-sources: wages, profit of enterprise, interest and ground-rent. Hence all are caught up as players in the gainful game, not just the ostensibly 'insidious' or 'greedy' capitalists.

According to Grimm: "Winnings (Gewinn) are associated with winning (attaining something through struggle, labour)." With this definition, only a human action would be addressed. The definition also takes account of the contingency - the fortune, chance, hap, luck - at play in the pursuit of winnings. The manifold of winning as the essential kernel of capital signifies more originarily and more uncannily the gathering of all modes of possible gain in which humans, too, are drawn into and are (or can be) used by the circular self-movement of valorizing value. Only from a human perspective does the gathering of the gainable appear entirely as a goal that is achieved by struggle and labour. The gathering of the gainable as a constellation of being's shaping up and disclosure in an historical age, however, makes everything that is (exists) appear within this hermeneutic cast as valorizable material. In this way, it entices and ensnares humans in an endlessly desirous, grasping striving.

The historical essence of capital is thus not anything merely capitalist but rather the reified consummation in our own historical time of what Plato and Aristotle call $\pi \lambda \varepsilon \operatorname{cov} \varepsilon \xi i \alpha$ (cf. Chapter 4 i), iv), Chapter 6 i) ), the striving for more to which all succumb to a greater or lesser extent. Capital's essential nature is neither the principal sum of money that is augmented, nor the dodgy ethos of a subject that is greedily or otherwise after monetary gain. It is neither money nor the lust for money, neither something objective nor subjective, but a calculating, 'gainful' mode of revealing the totality of beings in whose clearing everything appears as valuable insofar as it is seen as having the potential for winnings, so that humans are called on by the hermeneutic cast of the gainful game as players and compelled to think in a thoroughly calculative, albeit risk-taking, manner that sets up everything in the self-evident sight of a potential for gain. The gainful game is an hermeneutic cast of being that holds sway as a prevailing mode of disclosure of beings as a whole in an historical age. Since it is an hermeneutic message shaping a world, the essence of capital cannot be tied down to any 'thing', even though everything that can be valorized ultimately has a relation to money, i.e. a price. Nor is capital the self-interested 'invention' of a social class, the 'bourgeoisie'.

Marx himself speaks of value as a social relation, which suggests that it is constituted by sociated humans themselves, of course, without their knowing what they are doing, i.e. unconsciously. ("They don't know it, but they do it." ${ }^{13}$ ) The concept of the gainful game, by contrast, does not aim at anything made or conjured up by humans and a fortiori not at anything merely social, but as a cast of hermeneutic disclosure of beings as beings that has always already targeted possibilities of gain and which calls forth the corresponding human re-actions and social structures, i.e. the corresponding modes of being-together. The sociating of human beings accomplished by the historical socio-ontological hermeneutic cast of the gainful game does not posit merely capitalist, gainful social relations among (pre-existing) human beings, but constitutes human beings themselves as competitive players, i.e. human beings' very being as limitlessly desirous is constituted by the gainful game that comes over them as an eerily self-evident cast of thought.

13 "Sie wissen es nicht, aber sie tun es." Das Kapita/Vol 1, MEW23:88. 
In Marx, the value relation remains in the economic and social realm; it is, in the first place, the moneymediated social relation of commodities to each other which covers up and distorts the relations of people to each other. Capital as a social relation mediated by things provides the economy with its ontological form and form of self-movement and also constitutes the basis upon which a superstructure is erected. The other social instances - the state, the legal forms, morality, culture, ideologies, philosophy, etc. - are supposed to be thought proceeding from this basis and in a correspondence to it. According to the (never completed) program of Historical Materialism, ${ }^{14}$ a social whole is to be thought through dialectically in this way: the bourgeois social totality, that is, a structured totality of beings. The present article, by contrast, attempts to take capital and the valorization of value back to something more originary, namely back to a constellation of disclosive truth in an historical time in which all beings appear as what and as who they are.

Everything is, everything rates as existent, only to the extent that gain can be had from it. Everything that does not allow itself to be drawn into some circuit or other of valorization, through which advanced capital can be augmented, is not (is worthless). Everything is only insofar as, ultimately, a capital sum can generate from it winnings as offspring. The gathering of the gainable challenges all beings to allow themselves to be drawn with the promise of gain into the circuit of valorization of total social capital, thus contributing to its accumulation. The gathering of the gainable thus sets all beings into motion by sucking everything a priori into the risk-taking calculus of valorization, of winning and losing.

All beings appear refracted through the prism of reified value. Use for humans is not the criterion, but, ultimately, use for a circuit of valorization, for the gainful game which turns endlessly within itself, throwing off winnings and gain for all the income-source owners. Even untouched nature can be and is valorized in the gainful game, not only through the exploitation of natural resources, but also, say, as a recreational value for valorizable humans, who in turn are employed by the circuit of valorization as labourers and clerks and managers. A valorization of untouched nature is even conceivable via the value-category of ground-rent whereby the Earth's capacity to absorb pollutants such as carbon dioxide is marketed. ${ }^{15}$

Valorization is here no longer, as in its Marxian guise, only the augmentation of money-capital in a circuit, but is conceived more broadly as a striving to achieve success, and as winning and gaining in general, starting with earning the four basic kinds of income by the competitive players. ${ }^{16}$ Such gaining and winning always has a more or less tenuous monetary aspect, i.e. it can be expressed directly or indirectly in costs, savings, profits, surpluses, asset-values, goodwill, brand-value, personal savings and assets, celebrity-value, prestige-value, political influence and political power. Insofar, all beings can be quantified and incorporated into calculations on the basis of which the success or failure can be measured in a universal measure of value: money, and potentially or actually monetized. The gathering of opportunities for gain entices and ensnares humans in a competitive struggle for gain in the broadest sense, where they struggle with each other, and in this way, the gainful game valorizes and deploys human beings themselves.

\footnotetext{
${ }^{14}$ Marx announced his enormously ambitious program most famously in the 1859 Preface to his Critique of Political Economy. With the three volumes of Das Kapital, themselves left unfinished by Marx, and whose second and third volumes were edited posthumously by Engels, not even the very first stage of Marx's critical theory of bougeois society was completed. Cf. for more detail the Preface to M. Eldred, Critique of competitive freedom and the bourgeois-democratic state: Outline of a form-analytic extension of Marx's uncompleted system Kurasje, Copenhagen 1984, reissued with CreateSpace, N. Charleston 2015.

${ }^{15}$ Cf. M. Eldred 'Questioning the Earth's Value - Including a proposal for a capitalist carbon sink industry' 2005/2006 available at www.arte-fact.org.

16 Cf. M. Eldred Social Ontology loc cit. Chapter 6 viii) )
} 


\section{Reified value and the striving to be highly estimated}

The value for valorization cannot be restricted directly to monetary value but indirectly covers everything that can be won from beings as gain and success. Even though certain kinds of success cannot be turned directly into cash, a connection with money-value is nevertheless maintained insofar as success can be monetized. Success can show itself, however, also simply in the form of a gain in social reputation, status and prestige, i.e. as gaining a successful stand in whoness, ${ }^{17}$ which may or may not then, in turn, be 'cashed in' for monetary gain. The striving for gain in this case assumes the phenomenal form of vanity as a thirsting to have one's who-status estimated highly by others, and this thirsting, in turn, sprouts also a striving to have more of those "conveniencies of life" (Adam Smith) which one 'deserves'. The same holds true also for successfully gaining political power which may or may not be used as a currency for monetary gain.

Success, however, need not be linked ultimately to monetary gain at all. Value need not be thought as ultimately convertible into reified value, but as the value of being estimated and esteemed by oneself and others in one's status as somewho. This signification of value is covered by the Greek word, $\tau u \mu \eta$, which can mean not only the monetary price of things, i.e. of whats, but also the esteem, estimation and honour accorded to persons, i.e. to whos. Such a conception of value has the potential to break the link with the valorization of reified value in the Marxian sense, instead opening the vista on the interplay of whoness in a striving for esteem and self-esteem whose spectrum ranges from the estimation of genuine excellence through to defective forms of appearance such as the tawdry estimation of merely vain fame and celebrity, or the insufferable self-esteem of overweening narcissism.

Such striving for high valuation as somewho is called $\phi 1 \lambda \circ \tau 1 \mu t \alpha$, the 'love of honour and esteem', by Plato and Aristotle, in whose usage it has largely pejorative connotations in connection with perversions of striving to be esteemed highly, including those mediated by reified value, such as ostentatious consumption indulged in by the wealthy and politically powerful. But this is not the topic here and would take us too far afield. ${ }^{18}$ Rather, the concern at present is to espy a possible twist in the valorization of reified value by seeing through the fetishism of reified value.

\section{Seeing through the fetishism of reified value}

The value-form analyzed by Marx thus can be traced back to a more originary valorization in an historicotemporal cast in which the totality of beings opens up and beings show themselves a priori from the perspective of potential contribution to gain. The reason for the non-originariness of the Marxian analyses of the valueform is that they mainly tease out the contradictions between private and social, i.e. particular and universal subjectivity with the aim historically healing and overcoming them in a consciously sociated, universal subject.

The fetish character of the value-form includes that the products of human labour have assumed an autonomy vis-à-vis human subjectivity and therefore evade its control. Subjectivity/objectivity as the metaphysical environment in which Marxian thinking abides is, however, not originary, but is in turn grounded in an historicotemporal hermeneutic cast that casts as what the totality of beings reveals itself to be, without lying simply at the disposition of human actions as a 'production'. Marx proposes a revolution to bring renegade objectivity, which is thought under the rubric of fetishism, back under the political power of an authentically sociated,

${ }^{17}$ Cf. R. Capurro, M. Eldred, D. Nagel Digital Whoness Identity, Privacy and Freedom in the Cyberworld ontos/deGruyter, Frankfurt/M. 2013. Cf. also H. Arendt The Human Condition 2nd ed. with an introduction by Margaret Canovan, Chicago U.P. 1998, 1st ed. 1958.

${ }^{18}$ Cf. M. Eldred Phänomenologie der Männlichkeit Dettelbach: Röll 1999 and 'Was heißt Männlichkeit?' arte-fact.org 2013. 
social subjectivity, in which collectivized human beings are now consciously mediated socio-political subjects, but this by no means implies that the totality of beings would cease to reveal itself as a gathering of opportunities for gain for endlessly desirous human beings engaged in endless power struggles or even that there would be a twist in such disclosure. Witness the historical example of 'real-existing' state socialism. Rather, for such a twist, the orientation of a hermeneutic cast of free and fair estimating interplay is required.

If, therefore, we must take leave of the modern metaphysics of human subjectivity in the form of collectively labouring human beings as what is, or ought to be, underlying, this leave-taking has implications not solely for the value concept, which now can no longer be traced back ultimately to human labour as abstract valuesubstance. Not only is the labour theory of value untenable as a quantitative price theory; ${ }^{19}$ it is moreover tacitly based on certain metaphysical presuppositions of Feuerbachian anthropology according to which everything that is, including forms of ideology, is ultimately a human product; this subjectivist anthropology now must be seen through and gotten over. Accordingly, the value concept must now be thought without a pro-ductive relation to human labour or even humankind as that which ultimately underlies, but as the valuableness of beings, of both whats and whos, themselves which is neither subjective nor objective, but rather a quasi-Hegelian subjective-objective 'idea', here understood as an historico-hermeneutic cast that leaves the subject/object dichotomy behind altogether.

If the valorization of reified value cannot be traced back originarily to a production, i.e. to a bringing-forth, by human labour in which surplus value is siphoned off, it can nevertheless be conceived more temporally as a bringing-about (Zeitigung) of valuation in an interplay of competitive struggle, i.e. as a power play in which the as yet unreified abilities of all kinds, including entrepreneurial abilities, vie for tangible, monetary, value recognition and estimation. The totality of beings opens itself to us human beings as valuable - and therefore as worth desiring, as desirable - in the broadest spectrum that includes even what is worth-less, value-less. This valuableness comprises not only the usefulness (being-good-for...) of things and persons in the broadest sense of being appreciated, estimated and valued for a certain use, but also the value of being seen and reflected in a good light by others, being appreciated and highly estimated by others, in the first place, in having one's abilities recognized, validated and rewarded through reflection in the "value-mirror". ${ }^{20}$

Money is the purest social crystallization of this valuableness as the reified, tangible mediator in the dimension of valuableness that provides also the quasi-universal measure for all that is valuable. Money itself as the representative of wealth in general is the universal key to what is valuable by means of exchange and so itself, as a reified social power, becomes desirable as the focused aim of the striving for gain. The open gathering of opportunities for gain entices human beings into a striving for gain that, from another perspective, is nothing other than the reified movement of value as capital which sets all beings into motion for the sake of gain in the form of capital accumulation, thus becoming a circular end in itself and insofar senseless.

Learning to see economic value, at least, as residing first of all in the estimating interplay of human powers and abilities on the basis of mutually beneficial interchange in which reified value in the form of money serves merely as mediator, and is thus defetishized, could be an historical way of gaining distance from the capitalist valorization of reified value. I will take up this thought again below.

\footnotetext{
19 Cf. Social Ontology op. cit. Chapter 6 iii).
}

20 "Wertspiegel" Das Kapita/Vol. I MEW23:72. 


\section{The set-up}

In order to assess the uncanny nature of the movement set in train by fetishized, reified value-forms and put it into relation with the metaphysics of exchange, interchange and interplay ${ }^{21}$ as well as Adam Smith's famous notion of the invisible hand, it is helpful to draw on Heidegger's thinking on the set-up (Gestell) as the essence of modern technology. We read in a lecture given by Heidegger in Bremen in 1949:

Setting-up sets up by order22. It challenges. If we consider it in its essence and not according to possible effects, however, ordered setting-up does not aim at booty and gain/winnings (Gewinn), but always at what can be ordered to set up. 'Always' means here: a priori, because essentially, ordered setting-up is only dragged forth from one being that can be pro-duced to the next because ordered setting-up has from the outset always already torn everything present into a total availability for being set up by order and sets it up in this total availability - no matter whether in an individual case the present being may be specifically set up or not. This violent force of ordered setting-up that surpasses everything only draws the specific acts of ordered setting-up in its wake. The violent force of ordered setting-up suggests that what is called 'ordered setting-up' here is no mere human act, even though humans belong to the execution of ordered setting-up. ${ }^{23}$

Despite all this "violent force of ordered setting-up" that "surpasses everything", the chain of ordered settingup, according to Heidegger,

comes to nothing, for ordered setting-up does not set up anything in presence that could have or could be allowed to have a presence for itself outside setting-up. What is ordered into the set-up is always already and always only set up in order to set up in success an other as its successor. The chain of ordered setting-up does not come to anything; rather, it only goes back into its circling. Only in this circling does what can be ordered into the set-up have its stand. ${ }^{24}$ ('Das Ge-Stell' GA79:28f)

Heidegger thinks here ordered setting-up as the essence of nihilism, that comes to nothing, circling only in its "aim-lessness" (Ziel-losigkeit ${ }^{25}$ ) and senselessly drawing all beings into its incessant circular movement. Human beings themselves cannot be the subject of this constellation of being called the set-up because they, too, are drawn into "absolute servitude" (unbedingte Dienstschaft, XXV ibid. S. 87), degraded to the status of mere

${ }^{21}$ Cf. Social Ontology op. cit. Chapter 5.

22 'Setting up by order' or 'ordered setting up' renders 'Bestellen' and aims at capturing the polysemy of ordering as commanding, putting into order and placing an order (for some commodity). Beings are ordered into position, they are put into the order of the setup and they are ordered just like items in a mail order catalogue.

23 "Das Bestellen stellt. Es fordert heraus. Das Bestellen geht jedoch, wenn wir es in seinem Wesen bedenken und nicht nach möglichen Wirkungen, keineswegs auf Beute und Gewinn, sondern immer auf Bestellbares. 'Immer', das sagt hier: im vorhinein, weil wesenhaft, das Bestellen wird nur deshalb von einem Herstellbaren zum folgenden fortgezogen, weil das Bestellen zum voraus alles Anwesende in die vollständige Bestellbarkeit hingerissen und dorthin gestellt hat, mag das Anwesende im Einzelfall schon besonders gestellt sein oder nicht. Diese alles überholende Gewalt des Bestellens zieht die gesonderten Akte des Bestellens nur noch hinter sich her. Die Gewalt des Bestellens läßt vermuten, daß, was hier 'Bestellen' genannt wird, kein bloßes menschliches Tun ist, wenngleich der Mensch zum Vollzug des Bestellens gehört." M. Heidegger 'Das Ge-Stell' Gesamtausgabe Vol. 79 Klostermann, Frankfurt/M. GA79:29f, emphasis in the original.

24 "...läuft auf nichts hinaus; denn das Bestellen stellt nichts her, was außerhalb des Stellens ein Anwesen für sich haben könnte und dürfte. Das Be-stellte ist immer schon und immer nur daraufhin gestellt, ein Anderes als seine Folge in den Erfolg zu stellen. Die Kette des Bestellens läuft auf nichts hinaus; sie geht vielmehr nur in ihren Kreisgang hinein. Nur in ihm hat das Bestellbare seinen Bestand. 'Das Ge-Stell' GA79:28f.

${ }^{25}$ Martin Heidegger 'Überwindung der Metaphysik' XXI in Vorträge und Aufsätze Neske, Pfullingen 1985 S. 85. 
"employee" (Angestellte) inserted into the set-up and employed as its "most important raw material" (ibid. XXVI S. 91).

The quintessential formula for Heidegger's questioning of the modern world thus become the "will to will", a formula forged from his long critical engagement with Nietzsche and the latter's formula of the "will to power". The ghostly 'subject' of the ceaseless circling of the set-up is named as "the will to will", a will that wills only "the absolute and complete securing of itself". ${ }^{26}$ The will to will is thus not a subject but a ghostly presence that comes over everything, emitting an enticing siren call that draws all beings into a circular movement of setting-up for the senseless sake of setting-up. According to Heidegger, the origin of this setting-up, is the productive know-how that has its beginnings in Greek $\tau \dot{\varepsilon} \chi \nu \eta(\pi \circ \imath \eta \tau \kappa \eta \eta)$, i.e. productive technique, and which provides the paradigm for all Western metaphysical thinking, including its theological thinking. The ancient Greeks already thought being as having-been-produced (Hergestelltsein), as having been brought forth into standing presence, and Heidegger sees modern technology, enabled by the exact, mathematized sciences that arose in the seventeenth century, in its absolute domination as the historical culmination of this metaphysical hermeneutic cast. Instead of "will to will", I prefer to call this ghostly background presence the absolute will to effective and efficient mastery of all movement and change ${ }^{27}$ which makes itself felt in all science and technology and, via these, in all kinds of economic production processes in which efficiency counts.

\section{Heidegger's one-eyedness}

Because of his single-minded focus on production, Herstellung, which conforms with the asserted onedimensional constellation of being he calls the Ge-Stell, Heidegger has to assert, as quoted above, "ordered setting-up in no way aims at booty and winnings, but always at what can be ordered to set up" ('Das Ge-Stell' GA79:29). But how is this assertion to be squared with Marx's socio-ontological insight into the essence of capital as the "restless movement of winning, gaining" (die rastlose Bewegung des Gewinnens, MEW23:168)? Heidegger remains totally blind to the phenomenon that all that is produced by the Gestell also has to estimated and validated in an interplay as value in order to be. This may seem at first sight to be an overly strong assertion.

In contrast to Heidegger's, Marx's thinking sheds ontological light not only on the capitalist production process, but also on the sociating exchange process through which the phenomenon of value first becomes visible in its form, its being, i.e. first comes about as such. The concept of value is the foundation of Marx's ontology of capitalism. And capital's movement consists not only of production process but also of circulation process, both of which are conceived crucially as movements of valorization of value, a crucial philosophical thought to which Heidegger remained oblivious. This concept of value remains ambiguous in Marx because, on the one hand, only through exchange does the form of value itself come about (and this form of value must be regarded as its being), but on the other, value is said to have a measurable quantitative substance residing in the "productive expenditure of human brain, muscle, nerve, hand, etc." (produktive Verausgabung von menschlichem Hirn, Muskel, Nerv, Hand usw., MEW23:58) whose agglomeration produces value (and not just brings it about in the evaluating interplay of exchange). Value in Marx's thinking is thus thought ambiguously both as coming about through the mirror interplay of exchange and also, true to the age-old paradigm of productionist metaphysics, as being produced by labour expended.

\footnotetext{
26 "Wille zum Willen [...] die unbedingte und vollständige Sicherung seiner selbst" GA79:84.

${ }^{27}$ Cf. Eldred, M. The Digital Cast of Being 2009/2011.
} 
I have criticized at length and in detail this latter conception of labour-value, which forms the basis of the famous labour theory of value. ${ }^{28}$ This faulty conception enables Marx to construct a Cartesian, 'law-like' type of theory of capitalist economy ${ }^{29}$ because, if labour is the substance of value, capital-value can be continually augmented through the extraction, congealing and reification of this substance by having labourers labour under the command of capital. Value is therefore 'substantially' pro-duced, brought forth through the production process, and the exchange of produced commodities on the market is then only the realization of already produced, substantial value, including a component part of surplus value, in money.

Against Heidegger's single-minded focus on production and the totalized, "pre-calculable" ${ }^{\prime 30}$ bringing-forth and setting-up of all beings in the set-up, and also against Marx's postulation of labour as a value-substance with a standing presence that can be calculably congealed and produced in a production process through extracting this substance from living labour power, I have undertaken to show that value is not produced, but comes about (sich zeitigt) relatively as the ongoing outcome of a mirroring interplay on the markets in which what is offered is subjected to a competitive price-valuation in the mirror of money. 31 The form of value, i.e. its being, is nothing other than this social process of estimation and validation. Value is, i.e. presences, only in being seen as such by human beings who are themselves involved in the mirror play of exchange as players in the gainful game. The markets as a whole are an ongoing interplay of valuation and estimation, and thus a comingto-be as valuable of all the abilities of those involved in the competitive struggle to have their abilities and efforts recognized and rewarded via the sociating value-thing, money. Value can only be thought in its being as a social concept which means, it can only be thought relatively, i.e. as a relation of estimating interplay. As such it is entirely without substance.

\section{Relative surplus value production}

Because value is a relational, ongoing outcome of a value mirror play, it can also circulate as capital via evaluating interchanges. Produced products and abilities and services offered directly or indirectly to society can only become and be values through the mirror of evaluating validation in other goods and abilities similarly offered. Because Marx, at least in his dialectical value-form analysis, locates value in the exchange process, his determination of the essence of capital as a restless movement of self-augmentation of value is closer to the phenomena as they show themselves in the market-mediated striving for gain. The goal of competitive striving, money, is conceived by Marx as reified value, and the incessant striving for money in its manifold forms of appearance holds the capitalist economy in its characteristic restless, augmentative movement which Marx ultimately thinks through in concrete, complex, conceptual detail in the (relatively neglected) Volume II of Capital on the Circulation Process of Capital.

Heidegger's conception, by contrast, can only postulate a ghostly "will to will" that asserts itself in an endless bringing-forth and setting-up without being able to conceptualize how this postulated "will" as essence appears, i.e. is mediated with the phenomena of everyday life in which the mobilization of beings is apparent. The very being of what is pro-duced by the Gestell is value, and such value only comes about as an outcome, and not as a product, through the social interplay in which these beings are estimated and come to belong as such to sociated human being.

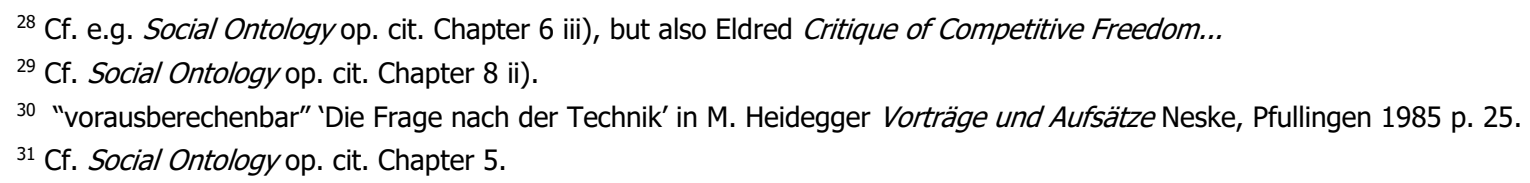


Marx's analysis of capitalism is also able to show precisely how the striving to increase productivity through the application of all sorts of technology - the power of bringing-forth - meshes with the essence of capitalism which he formulates as the valorization of value. The connecting link is what he conceptualizes as "relative surplus value production" in Part 4 of the first volume of Das Kapital. Even when the value-substance of labour-content is purged from the value concept as untenable, the striving to augment value considered in its money-form, i.e. in its 'money-being', can nonetheless still be enhanced by producing more productively because, other things being equal, greater productivity in comparison to lower productivity is invariably 'honoured', valued and estimated by the market in the ongoing competition with a greater monetary reward. All that is important here is the comparative or marginal or differential perspective: greater productivity, whether it be more quantity or better quality, gives an edge over competitors. The concept of relative surplus value production hence says that the employment of technology is a means of enhancing the chances of gain within that hermeneutic cast I have called the gainful game.

Technology is and can be employed as such a means because money-capital has the social power of developing or acquiring such technology by employing people in research processes. The power of bringing-forth is thus endlessly furthered because it intermeshes with the endless pursuit of monetary gain which, in turn, must intermesh with products being estimated and validated in the market mirror play in their being as valuable. Since Heidegger's conception of the set-up entirely lacks ontologically founded concepts of value and money, suffering as it does under a blindness to economic phenomenality in toto, the phenomenon of the link, through the mediation of an ontological concept, between the striving for gain and the striving to continually enhance productivity must remain in his thinking ontologically invisible and unfounded.

\section{Production (set-up) vs. exchange (gainful game)}

Both Heidegger and Marx, of course, diagnose the state of the world as being out of kilter. One could say their respective visions are dystopian rather than optimistic, but such commonplace judgements are frighteningly superficial, given that philosophical thinking aims in the first place at learning to see clearly our world-situation without comforting self-deception, including those idiotic political convictions that hinder any clearsightedness. Heidegger focuses on "the mad race of technology" (das Rasende der Technik, FndT VA:39), whereas Marx damns not only class exploitation (which depends on the untenable labour theory of value and must be rethought as grossly unfair interplay), but also the uncontrollable, subjectless process of valorization of value. For Heidegger, a major consequence of the unleashed technological way of thinking is the "devastation of the earth" (Verwüstung der Erde, 'Überwindung der Metaphysik' XXVIII Vorträge und Aufsätze S. 95).

But the earth remains sheltered in the inconspicuous law of the possible which the earth is. The will has forced on the possible the impossible as aim. The machination that sets up this compulsion and holds it in domination arises from the essence of technology, the word here being set identical to the concept of metaphysics in its self-consummation. ${ }^{32}$

He remains unconcerned with the unfair exploitation of working people by capital. Heidegger's diagnosis depends entirely on how he thinks Western metaphysics. The primary thesis, first formulated in 1922, remains

\footnotetext{
32 "Aber die Erde bleibt im unscheinbaren Gesetz des Möglichen geborgen, das sie ist. Der Wille hat dem Möglichen das Unmögliche als Ziel aufgezwungen. Die Machenschaft, die diesen Zwang einrichtet und in der Herrschaft hält, entspringt dem Wesen der Technik, das Wort hier identisch gesetzt mit dem Begriff der sich vollendenden Metaphysik." M. Heidegger 'Überwindung der Metaphysik' XXVIII Vorträge und Aufsätze op. cit. p. 95.
} 
to the end "being means having-been-produced"33. In the late text, 'The Question Concerning Technology', we even read, "Even $\phi v 0 i \varsigma$, the emergence from within itself, is a bringing-forth, is $\pi 0^{\prime} \eta \sigma r \varsigma^{\prime \prime}{ }^{34}$ When Heidegger searches around for what could save the earth from devastation and human being itself from total absorption in calculative thinking from being exhausted in "ordering setting-up" (Bestellen, FndT VA:38), he points therefore to something "related" because "any saving [power] must be of a higher, but at the same time related essence to that which is endangered". ${ }^{35}$ This related something that could save is therefore, Heidegger suggests, itself a kind of $\pi$ oin $\sigma \mathrm{i} \zeta$, namely "art" (Kunst, FndT VA:39). Also with his concept of Gelassenheit or 'letting-be', Heidegger sees the possibility of an alternative in dealing with the "mad race of technology" by stepping back from its imperious challenges.

Analogously, such Gelassenheit could serve also as a mild injunction to the siren calls of the manifold gathering of opportunities for gain that constitutes the constellation of being under capitalism and lead to a re-evaluation of what is valuable for dwelling on Earth. Refusing to heed and follow without limit the enticements of the possibility of gain in favour of living well, but frugally, within appropriate mortal limits is an echo of Aristotle's distinction between economics and chrematistics, as introduced in the first book of the Politics. It is an exercise of human freedom to set a limit to the pursuit of gain and, ultimately, only the free individual can say 'Enough!' and draw that line beyond which it refuses to participate in the hard, competitive power play of striving for gain. Such a freedom, of course, is not possible for an individual living on the edge of destitution. On the contrary, ways have to be invented to enable the poor to become adequate players in the value-gaining game in the first place.

I have already pointed to another possibility lying at the heart of metaphysics from its beginning, a possibility

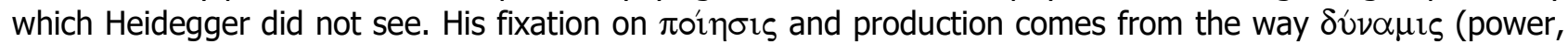
potential) is thought by Aristotle in his historically fateful ontology of movement as being the "governing starting-point for a change in something else" ( $\alpha \rho \chi \eta \dot{\eta} \mu \varepsilon \tau \alpha \beta 0 \lambda \eta \bar{\zeta} \varepsilon^{\varepsilon} \nu \alpha \lambda \lambda \lambda \omega$ Met. Theta 1, 1046a9f). In this formula for the ontological structure of the key phenomenon of movement/change, however, there is an ambiguity residing in the term $\mu \varepsilon \tau \alpha \beta 0 \lambda \eta$, which can mean both 'change' and 'exchange' or 'interchange'. This ambiguity opens the way for us to think through an ontology of exchange ${ }^{36}$ as distinct from traditional

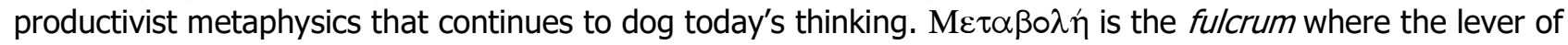
rethinking can be placed to pivot productivist metaphysics into an alternative ontology of interchange that at the same time enables the other to be recast hermeneutically as a free human being, i.e. as the source of his or her own life-movements in interplay with others. Into the ontological place of productive movement conceived as an actualization of productive power steps the alternative movement of social interplay that is always also a power play.

This alternative understanding of $\mu \varepsilon \tau \alpha \beta \circ \lambda \eta$ that has remained tacitly buried in Western thinking since the Greeks enables exchange and interchange to be thought ontologically as a groundless, estimating mirror interplay of powers, capable of providing the foundational kernel of a genuinely social ontology. This contrasts with Aristotle's productive ontology of movement, according to which all physical movement is modelled on the exercise of a grounded power of knowing on a 'material' to bring forth a change in something else, namely,

\footnotetext{
33 "Sein besagt Hergestelltsein" M. Heidegger, 'Phänomenologische Interpretationen zu Aristoteles (Anzeige der hermeneutischen Situation)' in Dilthey-Jahrbuch Volume 61989 MS:26.

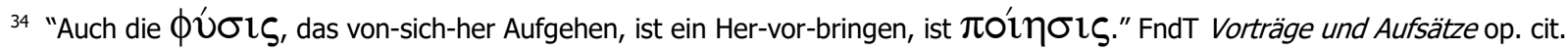
VA: 15 .

35 "alles Rettende höheren, aber zugleich verwandten Wesens sein muß wie das Gefährdete" FndT VA:38.

${ }^{36}$ Cf. Social Ontology op. cit. Chapter 5.
} 
the 'material', which may even be a human being. The concept of interplay also shows that, social power in general cannot be thought as productive power but - as long as it is not the exercise of brute physical violence - only through a relational game of mirroring estimation and validation in which a superior power is recognized as superior (if only as potentially physical violent) by a free human being and thus submitted to. ${ }^{37}$

What is salvatory in this pivoting side-step from productionist metaphysics is the possibility of thinking the competitive interplay of a capitalist market economy also in its ambiguous, Janus-faced possibility as an interchange of caring-for based on mutual self-interest and even on mutual satisfaction. An intensification of caring for each other in the mutual exercise of abilities of all kinds that are recognized, esteemed and appreciated as valuable in the ongoing metabolism of social interchange could represent an alternative that is "related" in the above-mentioned Heideggerian sense.

The set-up (Ge-stell) as the gathering of all possibilities of effectively bringing-forth and the gainful game (Gewinn-Spiel) as the gathering of opportunities for gain in gainful interplay are complementary constellations of a twofold, intermeshed way in which the world opens up for human being. Within this twofold hermeneutic cast of world in our present age, human beings strive for what contributes to living well or better, including mutual esteem, estimation and validation. An alternative to the restless pursuit of gain under the hegemony of the circuitous movement of self-augmenting capital resides first of all in seeing through the fetishism of reified value in all its forms of appearance in favour of seeing social interchange and interplay as opportunities for caring for each other. Such an historical alternative of fair, mutually beneficial interplay need not make (invariably vacuous and ineffective) appeals to altruism or brotherly love and solidarity.

Gainful interplay via markets can be regarded hermeneutically as a game of mutually estimating and esteeming each other's powers and abilities to do something for each other, thus serving and benefiting each other on a basis of freely given, mutual esteem. This should not be understood as a blue-print for Utopia, not only because any hermeneutico-ontological cast for an age comprises all deficient forms of the key phenomena in focus, but also because, in this particular case, a game of mutually beneficial estimation of powers and abilities remains always precisely a power play that can be played out with both fair and ugly moves. Moreover, other kinds of social power, particularly those of reified value (capital) and state political power, still exercise their power in power plays in ways that remain always contestable by self-aware, free people. Fundamentally, since all life is self-movement, it is also a play of powers and hence also often a power struggle.

The option of fair interplay in a reciprocal exercise of powers and abilities on a basis of mutual benefit is not a Utopian blue-print but can serve as orientation in a basic hermeneutic recasting of world that enables us to see through the many self-delusions that have long since become entrenched everywhere.

What does such an historical possibility of mutually esteeming interplay in conjunction with other contestable social power plays look like in today's context of the fast emerging cyberworld? Namely, it is not hard to see that what Heidegger called the set-up has attained its historical consummation in the algorithmically steered cyberworld ${ }^{38}$ that can be conceived as a concatenation of myriads of Turing machines. ${ }^{39}$

${ }^{37}$ Cf. Social Ontology op. cit. Chapter 10.

${ }^{38}$ Cf. Digital Whoness op. cit.

${ }^{39}$ Cf. M. Eldred 'Turing's Cyberworld' Information Cultures in the Digital Age: A Festschrift in Honour of Rafael Capurro Matthew Kelly \& Jared Bielby (eds.) Springer VS, Wiesbaden 2016 pp. 65-81. 


\section{The cyberworld}

\section{The cyberworld's freedom of movement}

The cyberworld is the artificial, global, electromagnetic medium for the movement of bit-strings of all kinds through it. Freedom of movement in the cyberworld relates first of all to bit-strings themselves, which are free to move in the same sense employed in physical dynamics for the motion of physical bodies. Freedom of movement for bit-strings thus signifies first of all a technical enablement of their motion through the cyberworld-matrix. ${ }^{40}$ Such bit-strings may be message data for communication between and among human beings, or they may be processing data transmitted as signals between digital devices, or they may be executable program code itself (i.e. algorithms), including malicious executable code. Freedom in the cyberworld is therefore initially an eery freedom for the cyberworld itself to unfold its digital powers of algorithmic control over all kinds of changes within and without the digitized electromagnetic matrix. The cyberworld unleashes its cybernetic powers of control upon the world as a whole, which can today be experienced ubiquitously in our everyday reliance upon and entanglement in such algorithmic processes that have ever greater impact on daily life-movements and -options. The outsourcing of segments of our own world-understanding in the form of algorithmic code into the cyberworld to then control specified movements and changes has long since gained such a frightening autonomy vis-à-vis the ostensibly underlying human subject, that it is sheer self-deception to believe that we can still enjoy a freedom of choice with regard to the cyberworld's rapidly exponentiating power.

\section{The gainful game unleashed in the cyberworld}

There is an intimate interconnection between the fluid motions of the cyberworld's bit-strings and the inherent tendencies of a global economy to mobilize everything and everybody in the pursuit of gain. As outlined above , we can learn from Marx thatcapitalist economy can be conceived as the movement of reified value in selfaugmenting cycles. Money-capital is advanced with the expectation and striving that it will return augmented with profit after all costs have been defrayed. All the various sorts of income-earners, not just the capitalists, are players in this now globalized gainful game. The cyberworld as a powerful, technically realized algorithmic network for efficiently controlling productive movement provides the opportunity i) for massive increases in productivity and hence cost reductions in all sorts of ways, especially through automating production and circulation processes and ii) for increasing the rate of turnover of capital, and thus profit rates, in particular by facilitating communications with employees, customers, suppliers, but also by automating and accelerating the transmission of signals for automatic algorithmic control of all kinds of processes.

In particular, the cyberworld enormously enhances the movement of money as cyber-digits. The movement of finance capital rapidly across the globe is also greatly facilitated by the cyberworld. Transactions of all kinds can now be done more speedily, including receipts to and from customers, payments to suppliers and employees, loan transactions with banks, and so on, thus reducing turnover-time. Today's banks have profited enormously by the introduction of digital automation, saving labour costs, cutting workforces and silently pushing the costs of transactions onto customers, who now have to purchase the digital equipment to communicate with their bank accounts and learn the ins and outs of their banks' software without the banks

\footnotetext{
${ }^{40}$ Cf. C.E. Shannon 'A Mathematical Theory of Communication' in The Bell System Technical Journa/ Vol. 27, July, October, 1948 pp. $379-423,623-656$, which aims precisely at such technical enablement. His theory is not one of communication, but of signal transmission.
} 
incurring any training costs. Entire capitalist enterprises can consist at core simply of cleverly written digital algorithms for controlling a certain specific type of commerical transaction, such as car-hire, that can be scaled up at minimal additional cost to make the enterprise global almost overnight.

Work productivity can increase through automated processes outsourced to the cyberworld and especially through the ease of communication with employees anywhere, anytime that turns employees themselves tendentially into appendages of their digital messaging devices, on constant stand-by for instructions from their superiors or new tasks to do.

An important aspect of the protection of personal privacy against encroachment by the cyberworld is to keep in place barriers to employees' becoming permanently contactable through the cyberworld, at their employer's, business associates', customers', etc. beck and call. Such constant availability as a 'labour power' amounts to an invasion of a personal life-world and a blurring of the line between work and private life.

For an income-earner of any kind, there is always the temptation to succumb to the siren calls of gainful opportunities offered by the cyberworld. Workoholic practices are encouraged by the ease with which work can continue digitally. An investor, for instance, can easily search the cyberworld for investment information and investment opportunities during his or her entire waking life. Hedge fund managers are particularly prone to keeping themselves constantly plugged into the financial information churned out second for second by the cyberworld. Managers can keep their digital device next to the bed at night to respond immediately to customer queries.

Hence it can be seen that the gainful game can be played in and through the cyberworld which, as a global medium, can lubricate and speed it up. The gainful game and the cyberworld are affine because reified value itself is quantifiable, and such quantities lend themselves to digitization in appropriate algorithms. Because the cyberworld is becoming more and more ubiquitous, all-pervading and all-encroaching, the players can be drawn more tightly into the gainful game's play. One could say that the cyberworld is an excellent medium for the freedom of the gainful game itself, which is dissociated from its pawns, the income-striving players themselves, and under the control of nobody, in particular, not within the grasp of state controls or subject to a wished-for 'primacy of politics'. Politics and the state can only try to regulate the rules of play.

The cyberworld thus extends the reach of and accelerates the gainful game otherwise known as capitalism. This is a two-edged development since, on the one hand, it enables many to earn an income who have been excluded from the gainful game and can even contribute to fostering entrepreneurship and alleviating poverty. On the other hand, the gainful game itself strengthens its hold on human life-movements, drawing them more and more into conformity with moves in the gainful game, now mediated and lubricated by algoritmically controlled movements of bit-strings. To be able to draw back from this tendency to be sucked in, human beings first need to learn to see the gainful game in its essential nature, which is not at all the case today.

What hinders insight is above all the hegemony of a productivist ontology of efficient, effective movement inherited from the Greeks that forms the tacitly presupposed foundation of all modern science, including even the social sciences. A genuinely social ontology requires an alternative guiding, orienting phenomenon, that of interplay, along with its appropriate conceptual hermeneutics, to enable an alternative cast of world to come historically to light. To date, philosophically speaking, we are still tapping in the dark or the semi-darkness of spurious philosophies upon which, among other things, self-delusive political ideologies are shakily based.

\section{Messages that matter}

Submerged beneath the bit-torrents that rage through the cyberworld are those messages that have nothing to do with either the effective algorithmic control of movement or with efficiently smoothing the valorizing circuit of some capital or other. Such messages between and among those few who have something to say to each other are useless from the perspective of both the set-up and the gainful game, yet they circulate in the electromagnetic medium as an aside. Insofar, the cyberworld is a medium like paper once was, and sometimes 
still is, for passing on subversive messages. Such angeletics ${ }^{41}$ bears tidings with the potential to recast the world, but only for those few at the present time with ears to listen.

Just as during the centuries of the Renaissance and the nascent Modern Age there were those who were sensitively open to messages of the dignity of the human subject (such as Erasmus and Pico della Mirandola) and the potential for precalculating movement by means of gradually mathematizing sciences (such as Kepler, Galileo, Descartes and Newton), today's message, as yet only faintly perceptible and apparently esoteric, tells of a recast world in which the interplay of mutually esteeming and estimating comes to the fore, especially with regard to what we humans can do for each other. Such interplay is essentially also a power play that has infinitely many (and often surprising) potential moves and countless nuances all the way from vicious struggles and desperate fights in all arenas - including in domestic and international politics, economic and private life - through to mutually beneficial and satisfying, fair play.

${ }^{41}$ Cf. R. Capurro \& J. Holgate (eds.) Messages and Messengers. Angeletics as an Approach to the Phenomenology of Communication Fink, Munich 2011. 


\section{References:}

Aristotle Met.

Aristotle Metaphysics in Works in Twenty-Three Volumes Vols. XVII \& XVIII Loeb Classical Library, London: Harvard U.P. and W. Heinemann 1938ff.

Aristotle Eth. Nic.

Aristotle Nicomachean Ethics in Works Vol. XIX.

Aristotle Phys.

Aristotle Physics in Works Vols. IV and V.

Aristotle Pol.

Aristotle Politics in Works Vol. XXI.

Capurro, Eldred \& Nagel 2013

Capurro, Rafael, Michael Eldred \& Daniel Nagel Digital Whoness: Identity, Privacy and Freedom in the Cyberworld ontos/deGruyter, Frankfurt/Berlin 2013.

Capurro \& Holgate 2011

Capurro, Rafael \& John Holgate (eds.) Messages and Messengers. Angeletics as an Approach to the Phenomenology of Communication Fink, Munich 2011.

Descartes 1996

Descartes, René Regulae ad Directionem Ingenii in Philosophische Schriften Meiner, Hamburg 1996.

Eldred 1984/2015

Eldred, Michael Critique of Competitive Freedom and the Bourgeois-Democratic State: Outline of a FormAnalytic Extension of Marx's Uncompleted System Copenhagen: Kurasje 1984, e-book edition www.arte-fact.org 2010. Reissued as paperback in North Charleston: CreateSpace 2015. With an extensive bibliography.

Eldred 2006/2013

Eldred, Michael 'Technology, Technique, Interplay: Questioning Die Frage nach der Technik' arte-fact.org. A slightly abridged version was published in Technology and Society Magazine IEEE Issue 2, Summer 2013 pp. 13-21.

Eldred 1996/2002

Eldred, Michael 'As: A Critical Note on David Farrell Krell's Daimon Life' www.arte-fact.org 1996/2002.

Eldred 1997/2010

Eldred, Michael Worldsharing and Encounter: Heidegger's Ontology and Lévinas' Ethics www.arte-fact.org Ver. 1.0 1997, Ver. 3.02010.

Eldred 1999

Eldred, Michael Phänomenologie der Männlichkeit Dettelbach: Röll 1999.

Eldred 2000/2010

Eldred, Michael Kapital und Technik: Marx und Heidegger Dettelbach: Röll 2000; english version in Left Curve No. 24, May 2000; www.arte-fact.org Ver. 3.0 2010. Also in Chinese translation by Lee Yanjun in German Thought Review (Deyizhi Sixiang Pinglun) Vol. 3, 2007.5, Tongji University Press, Shanghai pp. 37-112.

Eldred 2008/2011

Eldred, Michael Social Ontology: Recasting Political Philosophy Through a Phenomenology of Whoness Frankfurt: ontos/deGruyter 2008/2011; 2nd emended, revised, extended e-book edition, www.artefact.org 2011. With an extensive bibliography. 
Eldred 2015

Eldred, Michael A Question of Time North Charlston: CreateSpace2015.

Eldred 2009

Eldred, Michael 'Anglophone Justice Theory, the Gainful Game and the Political Power Play' www.artefact.org Ver. 1.0 2009; also in Eldred 2008/2011.

Eldred 2009/2011

Eldred, Michael The Digital Cast of Being: Metaphysics, Mathematics, Cartesianism, Cybernetics, Capitalism, Communication ontos/deGruyter, Frankfurt/Berlin 2009/2011; emended, revised, extended e-book edition at www.arte-fact.org Ver. 3.0 2011. With an extensive bibliography.

Eldred 2010

Eldred, Michael 'Values, social and beyond' in Indigo - Humanities Magazine for Young People Vol. 3 Busan, South Korea 2010 pp. 34-45. URL: www.arte-fact.org

Eldred 2011a

Eldred, Michael The Time of History: Hegel, Heidegger, Derrida, Marx www.arte-fact.org Ver. 1.02011.

Eldred 2011b

Eldred, Michael 'Circulating Messages to Every Body and No Body' in Messages and Messengers: Angeletics as an Approach to the Phenomenology of Communication Rafael Capurro \& John Holgate (eds.) Fink, Paderborn 2011 pp. 113-123.

Eldred 2012

Eldred, Michael Out of your mind? Parmenides' message www.arte-fact.org Ver. 1.0 2012.

Eldred 2012a

Eldred, Michael 'Turing's cyberworld of timelessly copulating bit-strings' www.arte-fact.org Ver. 1.02012

Eldred 2016

Eldred, Michael 'Turing's Cyberworld' Information Cultures in the Digital Age: A Festschrift in Honour of Rafael Capurro Matthew Kelly \& Jared Bielby (eds.) Springer VS, Wiesbaden 2016 pp. 65-81.

Hegel RPh 1970

Hegel, G.W.F. Rechtsphilosophie in Werke Bd. 7 Suhrkamp, Frankfurt/M. 1970.

Hegel VGPII 1971

Hegel, G.W.F. Vorlesungen über die Geschichte der Philosophie II Werke Band 19 Suhrkamp, Frankfurt/M. 1971.

Heidegger SZ 1927

Heidegger, Martin Sein und Zeit Niemeyer, Tübingen 1927, 15th ed. 1984.

Heidegger GA24

Heidegger, Martin Die Grundprobleme der Phänomenologie Marburger Vorlesung SS 1927 Gesamtausgabe Band 24 (GA24) ed. F-W. v. Herrmann, Frankfurt/M.: Klostermann 1975 English translation: The Basic Problems of Phenomenology Indiana U.P. 1982.

Heidegger $B H$

M. Heidegger 'Brief über den 'Humanismus' in Wegmarken Klostermann, Frankfurt/M. 2/1978.

Heidegger FndT

Heidegger, Martin 'Die Frage nach der Technik' in Vorträge und Aufsätze Neske, Pfullingen 1985.

Heidegger ÜdM

Heidegger, Martin 'Überwindung der Metaphysik' in Vorträge und Aufsätze op. cit.

Heidegger GA79

M. Heidegger 'Das Ge-Stell' Gesamtausgabe Vol. 79 Klostermann, Frankfurt/M. $1994 G A 79$.

Leibniz 1663/2003 
Leibniz, Gottfried Wilhelm 'Das Leib-Seele-Pentagon und die moralische Sphäre des Verstandes' (1663) in Frühe Schriften zum Naturrecht Hubertus Busche (ed.) Meiner, Hamburg 2003.

Marx 1974

Marx, Karl Grundrisse der Kritik der Politischen Ökonomie Dietz, Ost-Berlin:1974.

Marx 1962

Marx, Karl Das Kapital in Marx Engels Werke Bde. 23, 24, 25 Dietz, Ost-Berlin1962 Abbreviated MEW.

Marx 1859/1961

Marx, Karl Zur Kritik der politischen Ökonomie in Marx Engels Werke Bd. 13 Dietz, Ost-Berlin1961 Abbreviated MEW:13.

Marx 1968

Marx, Karl Ökonomisch-philosophische Manuskripte aus dem Jahre 1844 in Marx Engels Werke Ergänzungsband 1. Teil Dietz, Ost-Berlin 1968 Abbreviated ÖPM.

Seneca 1974

Seneca Ad Lucilium Epistulae Morales Wissenschaftliche Buchgesellschaft, Darmstadt 1974.

Smith 1759/2000

Smith, Adam The Theory of Moral Sentiments (1759) Prometheus Books, New York 2000.

Smith 1776/2000

Smith, Adam The Wealth of Nations (1776) edited with notes, marginal summary and enlarged index by Edwin Cannan, The Modern Library, New York 2000.

Turing 1936

Turing, Alan M. 'On Computable Numbers, with an Application to the Entscheidungsproblem' in Proc. Lond. Math. Soc. (2) 421936 pp. 230-265. 